\title{
Rental and Investment Regulation of Mining Companies in Subsoil Developing Industries
}

\author{
Gennady Alexandrov ${ }^{1}$, and Alexander Yablonev ${ }^{1, *}$ \\ ${ }^{1}$ Tver State Technical University, 170026, Af. Nikitin emb., 22, Tver, Russia
}

\begin{abstract}
Despite the fact that the problem of rental regulation of more and more becomes the object of scientists and practitioners attention, however, with regard to the results of the study of mining still cannot serve as a robust theoretical basis for the development of practical steps towards the establishment of organizational and economic relations and mechanisms, which would be able to determine the investment attractiveness of extractive activities and, consequently - the motivation to sustainable development. This is largely due to the fact that economic relations in mineral extracting industries, unlike other fields of activity are special. Their determinant is the existence of two types of band property relations, folding, firstly, regarding the ownership and administration of mineral resources, and, secondly, with regard to their use by entrepreneur as object of management. Therefore, between the owner of the subsoil and economic entity, there are special, rental relations in which inherently embedded contradiction in interests. It must and can be resolved solely on the principles of consensus and, we believe, through the institutionalization of these relations, their regulation and administration.
\end{abstract}

\section{Introduction}

The decision of marked problem we assume contained earlier provisions [1] that the basis for institutionalizing relations between the owner of the subsoil (in this case, the state) and the resource users should be based on the principle of their adequacy of objective relations of property and rental relations prevailing in the process. In turn, the realization of this principle supports the original condition using rental factor in shaping the investment attractiveness of mining areas, and, thus, provides an effective economic mechanism determining motivation and incentive to invest. This circumstance indicates by some foreign authors (see, for example, [2]).

Eventually, the principle of adequacy of specific (add-on) organizational and economic relations in the subsoil use is how they express the essence of the objective (basic) ownership and rent relations in the subsoil use process. Hence, the specific organizational and economic relations in the subsurface based on: firstly, the methodology for the analysis of rents and rental relations in terms of their impact on the investment attractiveness of extractive activities; secondly - the using sound method of division profits from extractive

\footnotetext{
* Corresponding author: alvovich@mail.ru
} 
activities (for example, peat mining), the part that takes the form of mining (natural) rents to be seized in favour of the owner of the field, and another part of it, in the form of business income attributable to an entrepreneur, business in this field; and, thirdly - the using the couple mechanism, based on rental regulation and tax administration are dealt with in the unity of opposites, and the removal of rent in favor of the owner of the subsoil occurs on the corresponding algorithm and takes certain organizational and legal forms.

\section{Materials and Methods}

Methodology of analysis such categories as rent and rent relations were largely considered us previously, primarily as factors contributing to attractiveness of extractive industries [1]. It is important to note that the possibility of institutionalizing rental relations inherently laid in essence rent relations, and the rent is a function of the state as the owner of the subsoil. This felt like the founders of classical political economy [3, 4], as well as their followers [5] and representatives of other currents [6], based on the fact that, on the one hand, that is, ownership of land and subsoil is the reason the emergence of rent, and, on the other, since the land and subsoil of created nature, they must belong to all of society and be subject to the state's attention.

Due to the fact that the rental relationship can be folded over the production and distribution of rents, the root problem here is defining its size, as well as the values of entrepreneurial income. As noted above, to solve this problem, a natural-value method of allocating rent from profits earned from extractive activities was justified and proposed by us [7].

The theoretical basis of this method is that the subsoil use relations led by the interests of the owner of the subsoil. Therefore, contrary to the assertions by some economists $[8,9]$ that rent is an addendum to the average profit, we associate ourselves with those who, on the contrary, believes, that no profit is the boundary of the rent and the rent is the boundary of profit [3]. In other words, the proposal to calculate rent as the difference between the gross profit from the sale of the extracted from the depths of the product and the normal, average profit, are not sufficient reason. In addition, they run counter to real practice, when preparing and signing the agreement, the owner of the resource, with, above all, their interests, tends to leave the user only such proportion of the product, which is sufficient for capital recovery, spent for the acquisition of inputs, and to receive regular (normal) return on investment [10].

In addition, the use of residual principle in determining the amount seized has arrived in the form of rents inevitably would result in less efficient use than the industry average, the profit shortfall would result in artificially reduce the rents due objectively produced the best natural quality of deposits. In other words, in this case, the user of bowels would implement his interests due to the owner of the subsoil. Therefore, in terms of what natural mineral deposits quality determines the size of the incremental product (and, hence - rent), or what is the same, the amount of the costs, as rightly indicated, the founders of classical economic theory, the end cost on the worst land serves as a yardstick to assess the rent amount, that is gained on all other lands. Thus, any other land brings so much more normal return to capital, how this plot gives more than the nastiest of the cropped plots [4]. As a result: "... the income of the poorest mine delivered not paying any rents, will regulate the rents of all other more productive mines. It is anticipated that this mine gives a normal return on capital. All that other mines give over her, will, of course, be paid to their owners as rent" [11].

As you can see from the above, the proposed approach quite adequately reflects not only the role of natural conditions in the production of incremental profits, which is the 
substance of the rent, but also the role of resource users and their capital in the production of another part of the profit constituting the substance of business income. But, anyway, the incremental profit produced, is a potential object of alienation, and only the owner of the subsoil could decide how much and order it will include her for alienation as rents in the user agreement.

\section{Results and Discussion}

Because we believe that the size of the withdrawal natural rents depends not only on the magnitude of its substance, incremental profits, but also on the purpose and character of the state policy of its withdrawing, then the latter should, as noted above, based on using the mechanism in which rental regulation and tax administration interact as unity of opposites, and the withdrawing of rent in favor of the owner of the subsoil occurs for a specific algorithm and in specific organizational-legal forms. It should be noted that the question of what should be the mechanism for withdrawal of rent remains extremely controversial. In most works are suggested "... withdrawing of differential rent... via taxes" and positively assesses the fact that Russia has a specific mechanism for withdrawing rental income, mainly through the general taxation system. It is noted that "... the current system of taxation of mining companies in insufficiently takes into account rental character of subsoil use, that reduce the effectiveness of the management of public property on the bowels", however, it is proposed to improve the system of taxation. At the same time, advocated the idea of such a phenomenon as "rental taxation", carried out by certain fiscal instruments [12].

Solving the problem is complicated by the fact that there is no understanding how taxes and tax administration in principle are able to perform a stimulation function and how they essentially have something in common with rental and rental payments. The authors of many publications disagree significantly on the implementation of tax incentive functions. Some researchers have drawn attention to the fact that the representatives of the state and policies tend to stick to a firm conviction of the relatively high importance of tax policy as an instrument for attracting investment. But they believe that tax incentives are not the most important factor in making investment decisions and play a secondary role, compared with other determinants, and questioned the argument that lower taxes increase investment attractiveness $[13,14]$. Others connect the stimulation role of taxes with specific phases of the economic cycle [15], the level of economic development of countries [16], industry characteristics [17], the quality of state management [18], etc.

In addition, it is noted that, for example, tax benefits and the level of tax payments differently influence on the execution of the tax incentive functions, giving preference tax benefits over a simple tax reductions $[13,15]$. In contrast, in other works on the basis of comparative analysis concludes that the introduction of tax benefits appear to be worthless, since no substantive link between the tax and the level of direct foreign investment was not found $[16,19]$. Some authors vice versa argue that, low tax rates are more effective, however, makes a reservation, that this is true mainly in respect to developed regions that already have sufficient volume of attracted investments [20]. Thus, it turns out, that about the stimulation role of taxes has not formed a view, which would have earned the recognition of the scientific community. In the face of uncertainty is very problematic regulation of rental relations by tax administration. In addition, the concept of "tax payments", "rental payments" or "rental taxation" - are irrational because rent and taxes are separate economic categories.

They have different origins and are totally different economic relations. Rent, substance which is produced extension income, caused by different natural conditions, is primarily a production category. At the same time, taxes are a category of distribution of the portion of 
the gross profit, which remains after deduction of rent. Therefore, it is possible to agree with the view that attempts to take into account the rent during taxation "are theoretically unfounded, because differential rent is formed on the field with deposit of minerals. The mine (subsoil plot) is subject of fee-use, and not the enterprise, having received access and right to use subsoil plot. In this case, the enterprise is the only taxpayer". The institutionalization of economic relations of subsoil use may simultaneously on two fronts, owing to differences in the economic nature of rents and entrepreneurial income and attach to different objects of economic relations: mine and enterprise.

This explains the state ability to run dual functions: regulation of the process of rent withdrawal from various natural quality of deposits, and tax administration of entrepreneurial income, attributable to a user after the gross profit will be removed and paid rent. Thus, the state, as the owner of the resource, can maintain the balance of interests in the relations of the subjects of the subsoil, and in addition, to ensure for the developer of the subsoil is common to all entrepreneurs, regardless of their type of activity, the order taxation, envisaged a unified fiscal policy. In other words, the state implements the principle of the equality of all subjects of entrepreneurship as part of the tax administration. As regards the actual rent regulation, their institutionalization is to develop "rules of the game" by the decision of such band tasks as, firstly, the establishment of mining rents sizes and the determination of its direction adjustment, and, secondly, the justification of expiration and selection of specific forms of user agreements concluded between the owner of the subsoil and subsoil users, as well as determining exemption order (payment) score mining rent.

The first task group is due primarily to the objective, natural factor. That is, each particular designed for the development field is different quality characteristics and, consequently, the size of the additional profit relatively worst natural conditions. Each of them has a certain life cycle (exploitability), during which the law of diminishing returns, since the deteriorating conditions of production. This in turn causes the need for adjustment in size of rents withdrawn. The decision of tasks that are part of the second group, represents a selection of specific forms and methods of solution (institutionalization) tasks that are part of the first group. With regard to the timing of subsoil use, pledged in a custom agreement, then the issue should be decided by their duration on the basis not only of the physical life cycle of deposits, but also from the standpoint of existing contradictions associated with formation of differential mining rent of second order, resulting from the investment and their impact.

The essence of this contradiction is that the entrepreneur, investing, expects that as a result he will receive additional profit for the validity period of the user agreement. At the same time, the owner of the deposit is by definition interested in as soon as possible remove this additional income in the form of differential rent of second order. The differences in interests, raises the need to resolve the specified controversies when deciding on the timing, which are user agreement. Since the state as the owner of the subsoil is interested to provide an enabling environment for investment one (so much so that natural rents it somehow gets under the terms of the current user agreement), it is quite feasible to do on the principles of consensus.

As regards the procedure for the withdrawal of rents, is largely in the form of regular, fixed payments, royalties, or in the form of one-time, essentially advance - lump-sum payment. From the standpoint of need to adjust rents withdrawn preferable is the use of royalties. Lump-sum payment in this regard not only does not meet the requirements of adjustment of rents, but also less attractive for subsoil users due to the fact that the possible risks associated with the exploitation of deposits over the long term, provide the mainly on subsoil users. In addition, lump-sum payment is usually used in cases where you want to cover the preliminary expenses of the owner deposits on preparing it for development. 
Therefore, economically justified, consistent with the interests of the owner deposits and entrepreneur-subsoil users, is the use of royalties. In practice, use different organizational and economic forms of user agreements. We do not put the task to give them a detailed analysis. Note that the choice of the form of such an agreement must provide for an adequate solution to all of the above tasks. The most common ones are: agreement in the form of lease or concession royalty - income tax type; and in the form of private-state partnership based on production sharing agreement.

Differences between arrangements of royalty-income tax type (or concession) and production-sharing agreement are as follows. Agreement type "royalty - income tax" provides for the granting of subsoil user ownership of produced products. The state in this case, leaving the subsoil user ownership of all harvested products, receives the right to withdraw from the subsoil user rents in the form of royalties, and taxes stipulated by the law. With regard to production sharing agreements, within the framework of the subsoil user in fact is a contractor of the state as the owner of the subsoil. When the license holder obtains ownership of only a fraction extracted products, equivalent to his business income, but, above all, giving the state a share of production equivalent to additional income, arising from the best natural conditions (natural rent) and tax on entrepreneurial income. As a result, the typical for royalty-tax on income agreement taxes and rental payments, is replaced by section products in accordance with the terms of the production sharing agreement.

Moreover, as practice shows, in comparison with the agreements of the type "royalty income tax", work in the form of a production sharing agreement is different in that the state collects from subsoil users tend to lower taxes. Therefore, it makes sense to use a form of the user agreement, as private-state partnership with the production sharing agreement especially during startup period.

\section{Conclusions}

Therefore, the current rent regulation system of relations with tax administration not apriori helps build motivation and incentives for rational, effective environmental management. As a result, it is almost impossible in such conditions the task of reaching a consensus in favour of subsoil users and state (as owner) and is a significant barrier factor on ways to revitalize the investment processes in the mining industry. All these facts objectively require the implementation of the concept of institutionalization of rental relations, principles which set out us in this article. The main thing in it is that the tax administration in relation to subsurface users (businessmen) combined with the regulation of the production and distribution processes, reasonable rental income in favour of the owner of the subsoil, thus provides a solution of contradictions for subsoil use entities on the basis of consensus and, in turn, contributes to the improvement of the investment climate in this area.

A study completed with the financial support of Russian Foundation for Basic Research (RFBR), the project "Development of a comprehensive method of investment climate diagnostics, evaluation and diversification of investment risks» N 17-02-00185 a. 


\section{References}

1. G. Alexandrov, A. Iablonev, E3S Web of Conf., 41, 04024. 2018

2. Ch.P. Jones, Investments: Analysis and Management (John Wiley \& Sons Inc., New York, 2012)

3. K. Marx, Capital. Critique of political economy (Verlag von Otto Meissner, Hamburg, 1885)

4. J.S. Mill, Principles of Political Economy (Oxford University Press, Oxford, 2008)

5. H. Spenser, Principals of Sociology (Appleton \& Co., New York, 1898)

6. C. Gide, C. Rist, A History of Economic Doctrines (George G. Harrap \& Co., New York, 1961)

7. G. Alexandrov, A. Yablonev, E3S Web of Conf., 21, 04011 (2017)

8. J. Schumpeter, A History of Economic Analysis (Oxford University Press, Oxford, 1954)

9. G.E. Ortega, A. Pugachevsky, G. Walser, Mineral rights cadastre. Oil, Gas and Mining Policy Division of the World Bank (NGAAD, Washington, 2009)

10. A. Smith, An Inquiry into the Nature and Causes of the Wealth of Nations, (Colin Muir and David Widger, London, 2009)

11. D. Ricardo, Compositions (John Ramsay McCulloch, London, 1846)

12. S.A. Kimelman, S.A. Andrushin, Problems of Economic Transition, 2, 83-92 (2005)

13. Y. Zelekha, E. Sharabi, Int. J. of Econ. Sc., 1:2, 138-159 (2012)

14. A.T. Tavares-Lehmann, A. Coelho, F. Lehmann, Progress in Int. Bus. Res., 7, 89-117 (2008)

15. E. Sims, J. Wolff, Eur. Econ. Rev., 107, 57-85 (2018)

16. A. Klemm, Int. Tax and Publ. Fin., 17:3, 315-336 (2010)

17. S. Anwar, Econ. Model., 26:3, 626-630 (2009)

18. S. James, Tax and Non-Tax Incentives and Investments: Evidence and Policy Implications (FIAS, The World Bank Group, Washington, 2009)

19. D. Barbosa, V.M. Carvalho, P.J. Pereira, Econ. Model., 52:B, 742-748,(2016)

20. M.P. Devereux, R. Griffith, H. Simpson, J. of Publ. Econ., 91:3, 413-435 (2007) 